\title{
Solusi Pencemaran Air Menggunakan Teknik Fitoremediasi Sebagai Bentuk Penerapan Model Project Based Learning di Masa Pandemi Covid-19
}

\author{
Vera Septi Andrini, Imega Syahlita Dewi, Hendrik Pratama
}

STKIP PGRI Nganjuk

vera@stkipnganjuk.ac.id

\section{Article History}

received 22/7/2021

\begin{abstract}
This study aims to determine the effectiveness of the implementation of the Project Based Learning model during the Covid-19 pandemic. The concept of project-based learning is applied in an effort to ignite student activity and critical thinking skills in learning. The research method used is a quantitative method with an experimental type. The research was conducted at STKIP PGRI Nganjuk with a sample of 49 students. Data collection techniques in the form of test instruments, questionnaires, and observations. Student activities are carried out in the form of a practicum project with the theme "Solution of Water Pollution Through Phytoremediation Techniques". The research results obtained are an increase in students' critical thinking skills. The data showed an increase if before treatment or pretest 0.24 (low criteria) to 0.41 (medium criteria). The results of the practicum data also show that phytoremediation using water hyacinth phytoremediator has proven to be effective in suppressing water pollution.
\end{abstract}

Keywords: Project Based Learning, Water Pollution, Phytoremediation, Covid-19

\begin{abstract}
Abstrak
Penelitian ini bertujuan untuk mengetahui efektifitas penerapan model pembelajaran Project Based Learning dimasa pandemi Covid-19. Konsep pembelajaran berbasis proyek ini diterapkan dalam upaya memantik keaktifan dan kemampuan berpikir kritis mahasiswa dalam belajar. Metode penelitian yang digunakan adalah metode kuantitatif dengan jenis eksperimental. Penelitian dilaksanakan di STKIP PGRI Nganjuk dengan sampel berjumlah 49 mahasiswa. Teknik pengumpulan data berupa instrumen tes, angket, dan observasi. Kegiatan mahasiswa dilakukan dalam bentuk proyek praktikum dengan tema "Solusi Pencemaran Air Melalui Teknik Fitoremediasi". Hasil penelitian yang diperoleh yaitu adanya peningkatan kemampuan berpikir kritis mahasiswa. Data menunjukkan peningkatan jika sebelum perlakuan atau pretest sebesar 0,24 (kriteria rendah) menjadi 0,41 (kriteria sedang). Hasil data praktikum juga menunjukkan bahwa fitoremediasi menggunakan fitoremediator eceng gondok terbukti efektif dalam menekan pencemaran air.
\end{abstract}

Kata kunci: Project Based Learning, Pencemaran Air, Fitoremediasi, Covid-19 


\section{PENDAHULUAN}

Permasalahan pencemaran air di Indonesia sudah sangat mengkhawatirkan. Berdasarkan data Kementerian Lingkungan Hidup dan Kehutanan (LHK), mulai tahun 2016 diketahui bahwa dari 140 sungai di 34 provinsi, sebanyak 73,24\% dalam status tercemar (Tim, 2017). Pencemaran air di Indonesia mayoritas disebabkan oleh aktivitas manusia, sampah pertanian, dan sampah industri, dan pertambangan. Sampah permukiman memiliki pemahaman semua bahan pencemar yang dibuat oleh wilayah permukiman atau rumah tangga. Sampah permukiman ini dapat berbentuk sampah organik (kayu, daun dll), dan sampah non organik (plastik, logam, dan detergent). Sampah pertanian memiliki pemahaman semua bahan pencemar yang dibuat aktivitas pertanian seperti pemakaian pestisida dan pupuk. Sedang sampah industri memiliki pemahaman semua bahan pencemar yang dibuat aktivitas industri yang kerap hasilkan bahan beresiko dan beracun (B3) (Prarikeslan, 2016).

Berdasarkan data dan fakta tersebut, perlunya peran berbagai pihak untuk mengatasi permasalahan pencemaran di Indonesia. Sudah menjadi peran peguruan tinggi tentunya untuk ikut serta mengatasi permasalahan ini. Berbagai upaya bisa dilakukan oleh perguruan tinggi. Seperti penanaman kepedulian mahasiswa dan seluruh civitas akademika untuk peduli lingkungan. Hal ini bisa diwujudkan melalui kegiatan perkuliahan. Penerapan pembelajaran berbasis ramah lingkungan perlu diberikan sejak dini. Selanjutnya, perguruan tinggi bisa bekerjasama dengan stake holder terkait seperti Dinas Lingkungan Hidup untuk bersama-sama mengatasi permasalahan yang ada. Salah satu program pembelajaran yang di Perguruan Tinggi adalah program green campus. Program ini memfasilitasi civitas akademika untuk turut berkontribusi dalam upaya mengatasi permasalahan lingkungan seperti pencemaran.(Buana, Wimala and Evelina, 2018)

STKIP PGRI Nganjuk sebagai salah satu kampus yang ada di Kabupaten Nganjuk senantiasa mendukung program peduli lingkungan. Hasil wawancara menunjukkan berbagai program kegiatan yang bertujuan untuk mengatasi permasalahan pencemaran lingkungan telah diadakan seperti penyiapan tepat sampah jenis organik, non organik, dan kertas. Hal ini dilakukan dalam upaya memupuk kepedulian warga kampus untuk membuang sampah pada tempatnya. Ada juga kegiatan sosialisasi bahasa pencemaran yang bekerjasama dengan desa-desa binaan. Selain itu, kegiatan prefentif seperti penanaman pohon yang bekerjasama dengan Dinas Kehutanan Kabupaten Nganjuk untuk melakukan reboisasi di daerah-daerah gersang. Semua kegiatan ini dilakukan secara kontinue untuk menekan permasalahan pencemaran yang ada.

Ditinjau dari sisi pembelajaran, perlunya sebuah model inovatif yang langsung membuat mahasiswa berkontribusi secara nyata dalam upaya mengatasi permasalahn disekitar. Seperti penerapan model Problem Based Learning (PjBL) sebagai solusi dalam upaya meningkatkan keterampilan dan keaktifan mahasiswa (Mustofa, Susilo and Al Muhdhar, 2016). Pembelajaran Berbasis Proyek (Project Based Learning) ialah sistem evaluasi yang memakai project/aktivitas sebagai media. Peserta didik lakukan eksploitasi, penilaian, interpretasi, sintesis, dan info untuk hasilkan bermacam-macam hasil belajar. ProPjBL sebagai mode evaluasi yang terpusat pada peserta didik untuk lakukan satu interograsi yang dalam pada sesuatu topik. Peserta didik secara konstruktif melakukan pengkajian evaluasi dengan pendekatan berbasiskan penelitian pada persoalan dan pertanyaan yang memiliki bobot, riil, dan berkaitan. Melalui penerapan model PjBL ini diharapkan peserta didik dapat mengaplikasikan secara riil ilmu yang diperoleh selama perkuliahan dan menerapkannya dalam kehidupan seharihari (Anggreni, Jampel and Diputra, 2020). Model ini juga bisa digunakan oleh peserta didik untuk melakukan penelitian mandiri seperti membuat hipotesis kemudian mencari solusi terbaik dari permasalahan yang ada. Selain itu, tentunya kemampuan berpikir 
kritis peserta didik akan dilatih untuk terus menemukan inovasi dan terobosan dalam menghadapi berbagai situasi disekitarnya.

Pandemi Covid-19 telah berjalan demikian lama di Indonesia, hingga mengganti beragam faktor kehidupan, seperti dunia pengajaran. Pembelajaran yang sebelumnya bisa dilaksanakan langsung bertatap muka, tetapi selama saat wabah, hal tersebut mustahil dilaksanakan. Pemerintahan meningkatkan pembelajaran secara online, sesuai kekuatan tiap wilayah. Dengan pembelajaran online ini, diharap arah evaluasi tetap direalisasikan. Perguruan tinggi diseyogyakan mengoptimalkan pembelajaran, dengan evaluasi online, hingga akar evaluasi tidak menyusut dan pengalaman belajar peserta didik bisa didapat dengan optimal pada keadaan wabah(Bahasoan et al., 2020). Hingga perlu diperkembangkan model pembelajaran yang sesuai dengan memprioritaskan kegiatan peserta didik dengan optimal. Salah satunya mode evaluasi yang bisa diperkembangkan ialah Project Base Learning (PjBL) yang disamakan dengan keadaan wabah, di mana peserta didik belajar dari rumah. Metode PjBL ini efektif dalam upaya mengoptimalkan proses pembelajaran karena berorientasi pada produk (Yustina, Syafii and Vebrianto, 2020).

Berdasarkan permasalahan dan uraian latar belakang, maka dalam penelitian ini dilakukan kajian terhadap pengaruh model pembelajaran PjBL dengan pokok bahasan yaitu pencemaran air. Pokok kajian yang menjadi permasalahan yaitu solusi pencemaran air melalui teknik Fitoremediasi.

\section{METODE}

Metode yang digunakan dalam penelitian ini adalah metode eksperimen. Hasil yang diperoleh setelah penerapan model PBL dipaparkan secara deskriptif. Desain eksperimen yang digunakan adalah one group pretest-postest design (Jaedun, 2011).

Penelitian ini dilakukan di Program Studi Pendidikan IPA STKIP PGRI Nganjuk. Sampel dalam penelitian ini sebesar 49 mahasiswa yang menempuh mata kuliah IPA Terpadu. Teknik pengambilan sampel dilaksanakan dengan teknik purposing sampling. Pengumpulan data dilakukan dengan menggunakan instrumen tes, angket, dan observasi. Instrumen yang digunakan dianalisis untuk memperoleh instrumen yang valid dan dapat dipercaya. Analisis data penelitian menggunakan SPSS dengan uji paired sampel t test. Uji ini termasuk uji komparasi yang bertujuan untuk mengetahui perbedaan hasil sebelum dan sesesudah penelitian.

\section{HASIL DAN PEMBAHASAN}

Dampak Covid 19 yang membuat proses pembelajaran dilakukan secara daring dari rumah, menuntut setiap pendidik untuk kreatif dalam menerapkan berbagai metode pembelajaran yang tepat. $\mathrm{PjBL}$ salah satunya mode pembelajaran yang membuat pelajar aktif dan berdikari dalam belajar. Mode pembelajaran berbasiskan project ini bisa dipakai untuk mengaplikasikan pengetahuan yang telah dipunyai, melatih beragam ketrampilan berpikir, sikap, dan ketrampilan nyata (Sugiyanto et al., 2020). Sedang pada persoalan kompleks, dibutuhkan pembelajaran lewat interograsi, kerjasama dan uji coba dalam membuat satu project, dan memadukan beragam subyek (materi) dalam belajar. Dengan mengaplikasikan mode pembelajaran berbasiskan project diharapkan mampu melatih kemandirian, kerjasama dan uji coba di dalam diri pelajar atau peserta didik (Puspasari, 2017; Widakdo, 2017).

Dalam penelitian yang dilakukan, kegiatan diawali dengan sebuah topik permasalahan. Topik yang diambil yaitu "Solusi Pencemaran Air Melalui Teknik Fitoremediasi". Sebagai langkah awal, siswa merencanakan proyek, bekerja dalam tugas yang kompleks, dan menilai kinerja dan kemajuan mereka. Sebuah proyek 
dirancang di sekitar isu-isu, pertanyaan atau kebutuhan yang diidentifikasi oleh peserta didik. Sebagai model pembelajaran, pembelajaran berbasis proyek mempunyai langkah-langkah seperti Gambar 1.

\begin{tabular}{|c|c|}
\hline $\begin{array}{c}\text { Menyiapkan pertanyaan atau } \\
\text { penugasan proyek }\end{array}$ & $\begin{array}{l}\text { - Tahap ini sebagai langkah awal agar mahasiswa } \\
\text { mengamati lebih dalam terhadap pertanyaan yang } \\
\text { muncul dari fenomena yang ada }\end{array}$ \\
\hline Mendesain perencanaan proyek & $\begin{array}{l}\text { - Sebagai langkah nyata menjawab pertanyaan yang } \\
\text { ada, disusunlah suatu perencanaan proyek bisa } \\
\text { melalui percobaan. }\end{array}$ \\
\hline $\begin{array}{c}\text { Menyusun jadwal sebagai } \\
\text { langkah nyata dari sebuah proyek }\end{array}$ & $\begin{array}{l}\text { - Kegiatan ini bertujuan agar target proyek dapat } \\
\text { diselesaikan tepat waktu }\end{array}$ \\
\hline $\begin{array}{c}\text { Memonitor kegiatan dan } \\
\text { perkembangan proyek }\end{array}$ & $\begin{array}{l}\text { - Tahap ini dosen bersama mahasiswa dapat } \\
\text { memonitoring perkembangan proyek dan jika } \\
\text { dimungkinkan melakukan perbaikan }\end{array}$ \\
\hline Menguji hasil & $\begin{array}{l}\text { - Fakta dan data percobaan dihubungkan dengan } \\
\text { berbagai sumber }\end{array}$ \\
\hline Mengevaluasi & - Tahap ini dilakukan evaluasi untuk melakukan \\
perbaikan proyek
\end{tabular}

\section{Gambar 1. Langkah Pembelajaran Berbasis Project Based Learning}

Berdasarkan Gambar 1, pertama dilakukan dengan merencanakan kegiatan praktikum Fitoremediasi untuk mengatasi pencemaran air. Tahap ini, siswa terlebih dahulu mencari data awal dan sampel penelitian untuk mengetahui pencemaran air yang ada disekitar. Kegiatan dilakukan secara berkelompok. Kedua, kelompok menyusun jadwal pelaksanaan kegiatan. Kegiatan dilanjutkan dengan uji lapangan dengan melakukan praktikum. Ketiga, monitoring lapangan yang dilakukan bersama dosen dan mahasiswa. Pada tahap ini, kegiatan monitoring dilakukan melalui Zoom Meeting karena pembelajaran masih dilaksanakan secara daring. Keempat, uji hasil dilakukan untuk mengetahui perbandingan hasil yang diperoleh dengan teori yang ada. Kelima, sebagai tahap akhir dilakukan evaluasi untuk melakukan perbaikan dan penyempurnaan proyek. Adapun hasil proyek praktikum fitoremediasi yang dilakukan mahasiswa untuk mengatasi pencemaran air dapat dilihat pada Tabel 1.

Tabel 1. Hasil Pengukuran pH Pada Praktikum Pencemaran Air
\begin{tabular}{llc}
\multicolumn{1}{c}{ Hari } & Perlakuan & Ph Rata-Rata \\
\hline Kesatu & Kontrol & 8,21 \\
\hline & Eceng Gondok 100 gr & 8,15 \\
\hline Kedua & Eceng Gondok 150 gr & 8,10 \\
\hline & Kontrol & 8,18 \\
\hline Eceng Gondok 100 gr & 8,02 \\
\hline Ketiga & Eceng Gondok 150 gr & 7,98 \\
\hline & Kontrol & 8,11 \\
\hline Keempat & Eceng Gondok 100 gr & 7,86 \\
\hline & Eceng Gondok 150 gr & 7,83 \\
\hline & Kontrol & 8,12 \\
\hline & Eceng Gondok 100 gr & 7,69 \\
\hline
\end{tabular}


Berdasarkan Tabel 1, tahapan fitoremediasi limbah cair dalam hal ini berupa air sungai dari sampel yang diambil tiap kelompok mahasiswa. Fitoremediasi menggunakan tanaman eceng gondok (Eichornia crassipes) yang diawali dengan dengan memasukkan kedalam botol air mineral air sungai yang diukur masingmasing 1 liter, kemudian setelah itu dilakukan penimbangan eceng gondok yang masing-masing diberikan perlakuan 100 gram dan 150 gram. Tahapan selanjutnya dilakukan dengan memasukkan eceng gondok dengan masing-masing massanya kedalam tiap sampel air sungai dan dilakukan pengamatan terhadap $\mathrm{pH}$ selama 4 hari.

Perlu diketahui bahwa syarat air yang baik adalah memiliki pH sekitar 6,5 sampai 7,5 atau dikatakan tidak tercemar jika memiliki pH mendekati 7 (netral) (Asrini, Adnyana and Rai, 2017). Namun demikian, data menunjukkan bahwa pada air kontrol rata-rata $\mathrm{pH}$ sebesar 8,15 . Hal ini mengindikasikan bahwa air terlalu basa atau bisa dikatakan tercemar. Setelah mengalami perlakuan, dilakukan pengukuran $\mathrm{pH}$. Hasil menunjukkan bahwa semakin besar massa eceng gondok yang diberikan untuk sampel air maka penurunan $\mathrm{pH}$ akan semakin besar pula, sedangkan pada kontrol tidak terjadi penurunan pesat dikarenakan tidak diberikan perlakuan eceng gondok. Rentang penurunan $\mathrm{pH}$ selama 4 hari pada sampel air dengan perlakuan massa eceng gondok 150 gram sebesar 7,62 sampai 8,10 mengalami penurunan yang lebih besar jika dibandingkan dengan sampel air tanpa perlakuan eceng gondok yang memiliki rentang penurunan $\mathrm{pH}$ yaitu 8,12 sampai 8,21 .

Dalam kegiatan ini yang perlu diperhatikan adalah bahwa selisih satu satuan angka $\mathrm{pH}$ itu artinya perbedaan konsentrasinya adalah 10 kali lipat, dengan demikian apabila selisih angkanya adalah 2 maka perbedaan konsentrasinya adalah $10 \times 10=$ 100 kali lipat. Sebagai contoh pH 5 menunjukkan konsentrasi H sebanyak 0.00001 atau $1 / 100000$ (seperseratus ribu) sedangkan $\mathrm{pH} 6=0.000001$ atau $1 / 1000000$ (sepersejuta). Dengan demikian jika kita menurunkan pH dari 6 ke 5 artinya kita meningkatkan kepekatan ion $\mathrm{H}+$ sebanyak 10 kali lipat. Misalkan $\mathrm{pH}$ itu gula, maka dengan menurunkan $\mathrm{pH}$ dari 6 ke 5, sama artinya bahwa larutan tersebut sekarang 10 kali lebih manis dari pada sebelumnya. Tidak semua mahluk bisa bertahan terhadap perubahan nilai $\mathrm{pH}$, untuk itu alam telah menyediakan mekanisme yang unik agar perubahan tidak terjadi atau terjadi tetapi dengan cara perlahan. Sistem pertahanan ini dikenal sebagai kapasitas pem-buffer-an.

Pada tahap akhir, dirumuskan secara bersama-sama penyebab dari kenaikan $\mathrm{pH}$ air sampel dengan efektifitas penggunaan fitoremediasi menggunakan eceng gondok. Hasil analisis siswa menunjukkan bahwa tercemarnya air sungai (sampel penelitian) disebabkan karena banyaknya warga masyarakat yang membuang limbah rumah tangga khususnya detergent ke aliran sungai, sedangkan penggunaan eceng gondok sebagai media fitoremediasi karena tanaman air ini hidup di perairan tawar yang menyerap nutrient untuk pertumbuhannya sebagai indikator fitoremediator yang efektif. Penyerapan nutrient dalam jumlah besar mengakibatkan eceng gondok tersebut menyerap limbah cair, N-Nitrat, dan logam-logam. Eceng gondok (Eichhornia crassipes) memiliki peranan penting diantara tanaman free floating karena efisiensinya dalam mengakumulasi berbagai logam berat dalam jumlah besar termasuk di dalamnya $\mathrm{Pb}, \mathrm{Cu}, \mathrm{Cd}, \mathrm{Fe}, \mathrm{Hg}, \mathrm{As}$, Se, Ag, Pt (Alfarokhi, 2016). Daun tanaman free floating mengandung konsentrasi logam berat yang tinggi dan merupakan hasil dari perpindahan aktif yang berasal dari sistem akar atau penyerapan langsung dari air (Poma Llantoy and Valderrama Negrón, 2014). Pengikatan logam berat pada tanaman jenis ini terbatas pada dinding sel atau sebagai agregat dengan fosfat dan kalsium yang terikat pada dinding sel endoderma. Logam umumnya terikat pada pektin atau protein yang terdapat dalam dinding sel tanaman (Eddy, 2015).

Fitoremediasi memiliki beberapa kelebihan jika dibandingkan dengan metode konvensional lain untuk menanggulangi masalah pencemaran, seperti : (a) Biaya 
operasional relatif murah (b) Tanaman bisa dengan mudah dikontrol pertumbuhannya. (c) Kemungkinan penggunaan kembali polutan yang bernilai seperti emas (Phytomining). (d) Merupakan cara remediasi yang paling aman bagi lingkungan karena memanfaatkan tumbuhan. (e) Memelihara keadaan alami lingkungan (Lee, 2013). Walaupun memiliki beberapa kelebihan, ternyata fitoremediasi juga memiliki beberapa kelemahan. Salah satu kelemahannya adalah kemungkinan akibat yang timbul bila tanaman yang telah menyerap polutan tersebut dikonsumsi oleh hewan dan serangga. Dampak negatif yang dikhawatirkan adalah terjadinya keracunan bahkan kematian pada hewan dan serangga tau terjadinya akumulasi logam pada predatorpredator jika mengosumsi tanaman yang telah digunakan dalam proses fitoremediasi (Shynta Abdari, 2012).

Berdasarkan kegiatan ini, tentu saja banyak hal yang bisa dikaji dari hasil proyek siswa. Kemampuan siswa meningkat, materi tersampaikan karena mahasiswa berupaya menemukan sendiri teori yang disampaikan, dan tentunya meningkatkan kemampuan berpikir kritis. Berpikir kritis merupakan kemampuan berpikiran secara reflektif dengan mengutamakan pada pengambilan keputusan mengenai apa yang harus dipercaya atau dilaksanakan (Puspitasari, Sumarmi and Amirudin, 2016). Indikator kemampuan berpikir kritis ada lima yakni (1) mampu merumuskan pokokpokok permasalahan; (2) mampu mengungkap fakta yang dibutuhkan dalam menyelesaikan suatu masalah; (3) mampu memilih argumen logis, relevan, dan akurat; (4) mampu mendeteksi bias berdasarkan sudut pandang yang berbeda; dan (5) mampu menentukan akibat dari suatu pernyataan yang diambil sebagai suatu keputusan (Rahma, 2012). Berpikir kritis sangat diperlukan oleh setiap orang untuk meyikapi permasalahan dalam kehidupan yang nyata. Berdasarkan hal ini, dilakukan uji kemampuan berpikir kritis sebelum dan sesudah perlakuan seperti terlihat pada Tabel 2.

Tabel 2. Statistik Deskriptif Skor Kemampuan Berpikir Kritis Siswa

\begin{tabular}{lccccc}
\hline \multicolumn{2}{l}{ Indikator Kemampuan Berpikir Krtitis } & \multicolumn{4}{c}{ Gain } \\
\cline { 2 - 6 } & Pretest & Kriteria & Postest & Kriteria \\
\hline $\begin{array}{l}\text { Mampu merumuskan pokok-pokok } \\
\text { permasalahan }\end{array}$ & 0,28 & Rendah & 0,43 & Sedang \\
\hline $\begin{array}{l}\text { Mampu mengungkap fakta yang } \\
\text { dibutuhkan dalam menyelesaikan suatu } \\
\text { masalah }\end{array}$ & 0,25 & Rendah & 0,37 & Sedang \\
\hline $\begin{array}{l}\text { Mampu memilih argumen logis, relevan, } \\
\text { dan akurat }\end{array}$ & 0,24 & Rendah & 0,41 & Sedang \\
\hline $\begin{array}{l}\text { Mampu mendeteksi bias berdasarkan sudut } \\
\text { pandang yang berbeda }\end{array}$ & 0,19 & Rendah & 0,35 & Sedang \\
\hline $\begin{array}{l}\text { Mampu menentukan akibat dari suatu } \\
\text { pernyataan yang diambil sebagai suatu } \\
\text { keputusan }\end{array}$ & 0,26 & Rendah & 0,51 & Sedang \\
\hline
\end{tabular}

Berdasarkan Tabel 2, kemampuan berpikir kritis siswa diamati berdasarkan 5 indikator. Pada indikator mampu merumuskan pokok-pokok permasalahan terdapat peningkatan rerata N-Gain dari 0,28 (kriteria rendah) menjadi 0,43 (kriteria sedang). Pada indikator mampu mengungkap fakta yang dibutuhkan dalam menyelesaikan suatu masalah terdapat peningkatan rerata N-Gain dari 0,25 (kriteria rendah) menjadi 0,37 (kriteria sedang). Pada indikator Mampu memilih argumen logis, relevan, dan akurat terdapat peningkatan rerata $\mathrm{N}$-Gain dari 0,24 (kriteria rendah) menjadi 0,41 (kriteria sedang). Pada indikator Mampu mendeteksi bias berdasarkan sudut pandang yang berbeda terdapat peningkatan rerata N-Gain dari 0,19 (kriteria rendah) menjadi 0,35 (kriteria sedang). Pada indikator mampu menentukan akibat dari suatu pernyataan yang diambil sebagai suatu keputusan terdapat peningkatan rerata N-Gain 
dari 0,26 (kriteria rendah) menjadi 0,51 (kriteria sedang). Dari kelima indikator yng telah ditentukan dapat disimpulkan bahwa kemampuan berpikir kritis mahasiswa meningkat. Keterampilan ini sangat penting dikuasai mahasiswa agar lebih terampil dalam menyusun sebuah argumen, membuat keputusan, dan memeriksa kredibilitas sumber. Pada capaian pembelajaran, kemampuan ini mutlak harus dimiliki (Dewanti, 2011).

Dengan kemampuan berpikiran kritis yang baik, pelajar tidak secara mudah menerima suatu hal yang diterimanya demikian saja, tapi pelajar dapat mempertanggungjawabkan gagasannya diiringi dengan argumen yang rasional (Sumarmo, Hendriana and Rohaeti, 2017). Kemampuan berpikiran kritis dapat melatih pelajar untuk dapat berlaku logis dalam menentukan dan memilih alternative opsi yang terbaik untuk suatu permasalahan, karena penting untuk memberikan kemampuan berpikiran kritis, karena itu berpikiran kritis perlu diberikan pada anak-anak sejak dini. Disamping itu, tugas pendidik untuk meningkatkan kemampuan berpikiran kritis pelajarnya, perlu memperhatikan karakter pelajar karena hakekatnya masing-masing pelajar mempunyai kelebihan-kelebihan begitupun keterbatasan-keterbatasan dengan kekuatan yang dimiliknya (Haryanti, 2017). Dengan demikian, dalam memahami dan menyerap pelajaran yang dikatakan pendidik tiap pelajar berlainan. Oleh karena itu, guru sebaiknya pahami jika ketidaksamaan dalam kekuatan itu memerlukan tindakanperlakuan yang memiliki sifat kelompok. Salah satunya hal yang penting diingat ialah style berpikiran tiap pelajar (Fuad et al., 2017).

Hasil penyebaran angket yang didapat melalui penerapan model PjBL pada materi pencemaran, diperoleh fakta bahwa mahasiswa benar-benar menyukai model pembelajaran ini. Media yang digunakan dalam penyampaian pembelajaran yaitu Google Classrom dan Zoom Meeting. Hal ini dilakukan karena mengingat masa pandemi yang mengharuskan proses pembelajaran dilaksanakan secara daring (Muqorobin and Rais, 2020). Hasil penyebaran angket menunjukkan bahwa (1) sebesar 91\% mahasiswa menyukai model pembelajaran Project Based Learning, (2) sebesar $89 \%$ menyatakan bahwa model pembelajaran berbasis proyek mampu membuat siswa lebih aktif dan ilmu yang diperoleh lebih mengena dalam hati karena mahasiswa terlibat langsung dengan obyek masalah, (3) sebesar $85 \%$ mahasiswa menyatakan bahwa penggunaan media pembelajaran seperti Google Classrom dan Zoom Meeting tidak terlalu memberatkan, (4) sebesar 95\% siswa merasa puas belajar karena selain materi menarik, juga ilmu yang diperoleh bisa langsung diaplikasikan di lapangan. Lewat praktikum memudahkan mahasiswa mempelajari materi karena dituntut untuk mencari solusi dan menguji secara eksperimen dilapangan. Mahasiswa lebih percaya atas kebenaran atau kesimpulan berdasarkan percobaan yang dilakukan sendiri daripada hanya menerima penjelasan dari pendidik atau dari buku. Selain itu, sikap-sikap ilmiah seperti bekerjasama, bersikap jujur, terbuka, kritis dan bertoleransi dapat terus dikembangkan. Praktikum jadi sarana belajar pendekatan ilmiah. Ini karena pada proses evaluasi praktikum tidak sekedar hanya keterkaitan peserta didik saja, namun dipengaruhi juga peranan langsung dari peserta didik dalam analisis permasalahan, mengumpulkan data, menganalisa dan membuat hasil praktikum dalam bentuk laporan. Penggunaan praktikum memberikan peluang kepada peserta didik untuk mendapati dan menunjukkan teori. Dengan demikian, praktikum bisa mendukung pengetahuan peserta didik pada materi pelajaran (Zahara, Wahyuni and Mahzum, 2017).

\section{SIMPULAN}

Berdasarkan hasil penelitian dan pembahasan, kesimpulan yang dapat diambil dalam penelitian ini adalah model pembelajaran berbasiskan project atau Project Based Learning mampu membuat pelajar aktif dan berdikari dalam belajar. Model pembelajaran berbasiskan project bisa dipakai untuk mengaplikasikan pengetahuan 
yang telah dipunyai, latih beragam ketrampilan berpikiran, sikap, dan ketrampilan nyata, dan tentunya mampu meningkatkan kemampuan berpikir kritis. Dengan menerapkan model pembelajaran berbasis proyek diharapkan melatih kemandirian, kolaborasi dan eksperimen didalam diri siswa atau peserta didik. Peningkatan kemampuan berpikir kritis berdasarkan data menunjukkan peningkatan jika sebelum perlakuan atau pretest sebesar 0,24 (kriteria rendah) menjadi 0,41 (kriteria sedang).

Rekomendasi yang dapat diberikan yaitu (1) perlunya model pembelajaran inovatif yang mampu membuat mahasiswa tetap aktif dalam melaksanakan pembelajaran dimasa pandemi, (2) perlunya topik-topik terkait permasalahan yang mudah untuk diaplikasikan mahasiswa secara riil tidak hanya sekadar teori saja, (3) perlunya monitoring dan evaluasi pembelajaran secara kontinue tidak sekedar saat perkuliahan. Dengan hadirnya mode daring, setiap saat pendidik bisa melakukan kontrol dan cek terkait permasalahan yang dihadapi mahasiswa.

\section{DAFTAR PUSTAKA}

Alfarokhi, A. I. (2016) 'Pemanfaatan Eceng Gondok (Eichhornia Crassipes) Sebagai Tumbuhan Fitoremediasi Dalam Proses Pengolahan Limbah Tambak Udang Vannamei'. UII Yogyakarta.

Anggreni, L. D., Jampel, I. N. and Diputra, K. S. (2020) 'Pengaruh Model Project Based Learning Berbantuan Penilaian Portofolio Terhadap Literasi Sains', Mimbar IImu, 25(1), pp. 41-52.

Asrini, N. K., Adnyana, I. W. S. and Rai, I. N. (2017) 'Studi Analisis Kualitas Air di Daerah Aliran Sungai Pakerisan Provinsi Bali', Jurnal Ecotrophic, 11(2), pp. 101107.

Bahasoan, A. N. et al. (2020) 'Effectiveness of online learning in pandemic COVID-19', International journal of science, technology \& management, 1(2), pp. 100-106.

Buana, R. P., Wimala, M. and Evelina, R. (2018) 'Pengembangan Indikator Peran Serta Pihak Manajemen Perguruan Tinggi dalam Penerapan Konsep Green Campus', RekaRacana: Jurnal Teknil Sipil, 4(2), p. 82.

Dewanti, S. S. (2011) 'Mengembangkan kemampuan berpikir kritis mahasiswa Pendidikan Matematika sebagai calon pendidik karakter bangsa melalui pemecahan masalah', in Prosiding Seminar Nasional Matematika, pp. 29-37.

Eddy, S. (2015) 'Kemampuan tanaman eceng gondok sebagai agens fitoremediasi air tercemar timbal (Pb)', Sainmatika: Jurnal IImiah Matematika dan IImu Pengetahuan Alam, 6(2).

Fuad, N. M. et al. (2017) 'Improving Junior High Schools' Critical Thinking Skills Based on Test Three Different Models of Learning.', International Journal of Instruction, 10(1), pp. 101-116.

Haryanti, Y. D. (2017) 'Model problem based learning membangun kemampuan berpikir kritis siswa sekolah dasar', Jurnal Cakrawala Pendas, 3(2).

Jaedun, A. (2011) 'Metodologi penelitian eksperimen', Fakultas Teknik UNY, 12.

Lee, J. H. (2013) 'An overview of phytoremediation as a potentially promising technology for environmental pollution control', Biotechnology and Bioprocess Engineering, 18(3), pp. 431-439.

Muqorobin, M. and Rais, N. A. R. (2020) 'Analysis of the Role of Information Systems Technology in Lecture Learning during the Corona Virus Pandemic', International Journal of Computer and Information System (IJCIS), 1(2), pp. 47-51.

Mustofa, Z., Susilo, H. and Al Muhdhar, M. H. I. (2016) 'Penerapan model pembelajaran problem based learning melalui pendekatan kontekstual berbasis lesson study untuk meningkatkan kemampuan memecahkan masalah dan hasil belajar kognitif siswa SMA', Jurnal Pendidikan: Teori, Penelitian, Dan Pengembangan, 1(5), pp. 885-889.

Poma Llantoy, V. R. and Valderrama Negrón, A. C. (2014) ‘Estudio de los parámetros 
fisicoquímicos para la fitorremediación de Cadmio (II) y Mercurio (II) con la especie Eichhornia crassipes (Jacinto de agua)', Revista de la Sociedad Química del Perú, 80(3), pp. 164-173.

Prarikeslan, W. (2016) 'Dampak Limbah Rumah Tangga Terhadap Ekosistem Laut Bagi Masyarakat Di Pasie Nantigo Koto Tangah Padang', JURNAL GEOGRAFI, 5(1), pp. 1-11.

Puspasari, R. (2017) 'Implementasi project based learning untuk meningkatkan kemandirian dan prestasi belajar mahasiswa dalam pembuatan alat peraga matematika inovatif', Math Didactic: Jurnal Pendidikan Matematika, 3(1), pp. 1022.

Puspitasari, E., Sumarmi, S. and Amirudin, A. (2016) 'Integrasi Berpikir Kritis dan Peduli Lingkungan Melalui Pembelajaran Geografi dalam Membentuk Karakter Peserta Didik SMA', Jurnal Pendidikan: Teori, Penelitian, dan Pengembangan, $1(2)$, pp. 122-126.

Rahma, A. N. (2012) 'Pengembangan Perangkat Pembelajaran Model Inkuiri Berpendekatan SETS Materi Kelarutan dan Hasilkali Kelarutan untuk Menumbuhkan Keterampilan Berpikir Kritis dan Empati Siswa terhadap Lingkungan', Journal of Research and Educational Research Evaluation, 1(2).

Sugiyanto, S. et al. (2020) 'Integration of mobile learning and project-based learning in improving vocational school competence', Journal of Technical Education and Training, 12(2), pp. 55-68.

Sumarmo, U., Hendriana, H. and Rohaeti, E. E. (2017) 'Hard Skills dan Soft Skills Matematik Siswa', Bandung: PT. Refika Aditama.

Tim, I. (2017) 'Catatan Akhir Tahun 2016 Indonesian Center for Environmental Law "Tahun Kelam Kebijakan dan Penegakan Hukum Lingkungan di Indonesia"', Jurnal Hukum Lingkungan Indonesia, 3(2), pp. 141-170.

Widakdo, W. A. (2017) 'Mathematical representation ability by using project based learning on the topic of statistics', in Journal of Physics: Conference Series. IOP Publishing, p. 12055.

Yustina, Y., Syafii, W. and Vebrianto, R. (2020) 'The effects of blended learning and project-based learning on pre-service biology teachers' creative thinking through online learning in the Covid-19 pandemic', Jurnal Pendidikan IPA Indonesia, 9(3), pp. 408-420.

Zahara, R., Wahyuni, A. and Mahzum, E. (2017) 'Perbandingan Pembelajaran Metode Praktikum Berbasis Keterampilan Proses dan Metode Praktikum Biasa terhadap Prestasi Belajar Siswa', Jurnal Ilmiah Mahasiswa Pendidikan Fisika, 2(1), pp. 170-174. 